Creative commons User License: CC BY-NC-ND

Abstracted by: EBSCOhost, Electronic Journals Service (EJS), Google Scholar, Directory of Open Access Journals (DOAJ),

Journal Seek, Scientific Commons,

Food and Agricultural Organization (FAO), CABI and Scopus
Journal of Agricultural Extension

Vol. 21 (1) February, 2017

ISSN(e): 24086851; ISSN(Print); $1119944 X$

http://journal.aesonnigeria.org

http://www.ajol.info/index.php/jae

Email: editorinchief@aesonnigeria.org

\title{
Perception of Modern Processing Technology by Shea Butter Processors in Kwara State, Nigeria
}

http://dx.doi.org/10.4314/jae.v21i1.1

\section{Akinsokeji, Oluwakemi Alaba}

Department of Agricultural Extension and Rural Development, Faculty of Agriculture and Forestry, University of Ibadan, Ibadan.

Email: akinsokejioluwakemi@yahoo.com.

Phone: 08065788621.

\section{Tijani, Sarafat Ayanfunke}

Department of Agricultural Extension and Rural Development, Faculty of Agriculture and Forestry, University of Ibadan, Ibadan.

Email: tsarafat@yahoo.com.

Phone: 08051370802.

\section{Sanusi, Mohammed Kabiru}

Nigerian Institute for Oil Palm Research (NIFOR) Date palm Sub-station, P.O. Box 30, Dutse, Jigawa State, Nigeria.

Email: sanusimk2004@gmail.com.

Phone: 08033638872.

\section{Igene, Lucky}

Extension Division, Nigerian Institute for Oil Palm Research (NIFOR), P.M.B. 1030, Benin City, Edo State, Nigeria.

Email: igenelucky@gmail.com.

Phone: 08068012422.

\section{Orifah, Martins Olusegun}

Department of Agricultural Economics and Extension, Federal University of Dutse (FUD), P.M.B. 7156, Dutse, Jigawa State, Nigeria.

Email: martinsorifah@gmail.com.

Phone: 08036976320

\section{Abstract}

The study examined the perception of Shea butter processors to modern processing technology in Kwara State. Multi stage sampling procedure was used to select 120 respondents. Data was collected using interview schedule and analysed with both descriptive and inferential statistics. Results revealed that $88.3 \%$ of the respondents were females between $40-50$ years of age (47.0\%) and have low level of education (83.1\%). The household size of the respondents was 5-8 members (65.9\%) and 1-10 years of experience (52.8\%).

Respondents' level of awareness of modern processing technology was high (55.0\%), pre-cleaner (98.3\%) and storage tank (94.2\%) being higher. The majority (62.5\%) had favourable perception to modern processing technology, sixty per cent strongly agreed and $61.0 \%$ agreed that modern processing 
Creative commons User License: CC BY-NC-ND

Abstracted by: EBSCOhost, Electronic Journals Service (EJS), Google Scholar, Directory of Open Access Journals (DOAJ),

Journal Seek, Scientific Commons,

Food and Agricultural Organization (FAO), CABI and Scopus
Journal of Agricultural Extension

Vol. 21 (1) February, 2017

ISSN(e): 24086851; ISSN(Print); 1119944X

http://journal.aesonnigeria.org

http://www.ajol.info/index.php/jae

Email: editorinchief@aesonnigeria.org

technology reduced drudgery and increase profit respectively. There was significant relationship ( $r=0.182, p=0.046)$ between respondent's level of awareness and their perception. Information should be disseminated to the processors in local languages on the benefits and how to use modern processing technology.

Keywords: Shea butter processors, Shea butter modern processing technology.

\section{Introduction}

The Nigerian agricultural industries have the potentials to contribute significantly to the economic and industrial development of the nation, especially with the wide range of the nation's agro-produce like Shea trees (Garba, et. al., 2011). Nigeria is abundantly blessed with Shea trees (vitellaria paradoxa) which could be harnessed for the industrial development of the country. The white ivory colour fat extracted from the nut is called Shea butter which has many uses in the edible oil, chocolate and beverage as well as pharmaceutical and cosmetic industries. The demand for the West African Shea butter has been on the increase in the recent time because of European Union approval of $5 \%$ inclusion of non-cocoa vegetable fat in chocolate manufacturing in 2000 (Harsch, 2001). Hence more industries in Europe and America are expressing interest in it.

Shea butter has similar chemical and physical properties with cocoa butter and uncertainty in the prices of cocoa butter in the world market makes Shea butter an instance alternative to cocoa butter. Cocoa butter equivalent (CBE) industries account for $90 \%$ of total Shea butter exports from West Africa while cosmetic and pharmaceutical industries absorb the remaining share (Yinug and Fetzer, 2008).

Nigeria having the largest Shea trees in the world (FAO Statistics, 2015) is expected to earn more foreign exchange likewise the processors are to earn more income from Shea butter. However, this is not so because of the decrease in demand for the country's Shea butter as a result of the use of 
Creative commons User License: CC BY-NC-ND

Abstracted by: EBSCOhost, Electronic Journals Service (EJS), Google Scholar, Directory of Open Access Journals (DOAJ),

Journal Seek, Scientific Commons,

Food and Agricultural Organization (FAO), CABI and Scopus
Journal of Agricultural Extension

Vol. 21 (1) February, 2017

ISSN(e): 24086851; ISSN(Print); 1119944X

http://journal.aesonnigeria.org

http://www.ajol.info/index.php/jae

Email: editorinchief@aesonnigeria.org

traditional method of producing Shea butter which is characterised by poor quality and low quantity. This is supported by Ademola, et al (2012) that Shea butter is mostly processed manually in small villages in Nigeria by village women using traditional methods which are passed down through generations.

The extraction rate of Shea butter from the nuts correlates with the mechanical input (Addaquay 2004). He affirmed that comparatively, the extraction rate of Shea butter from Vitellaria paradoxa using the traditional method is about $20 \%$, using semi-mechanised method is $35 \%$ to $40 \%$ and using the fully mechanized method is $42 \%$ to $50 \%$. The transformation of Shea nuts into butter using traditional method is a difficult task because it is tedious and drudgery. The process involves intensive physical labour as well as considerable amount of time, water and firewood. It is estimated that the production of 1 kilogramme of Shea butter takes one person 20-30 hours and that 8.5- 10 kilogrammes of wood fuel is needed to produce it (Bonkoungou, 2005). In order to improve the quality and quantity of Shea butter production in the country, the use of mechanized method is desirable because it is expected to reduce the human time, material resources in terms of water and fuel wood as well as drudgery associated with the use of traditional method.

There are many technologies that have been developed to perform almost all the different stages of the traditional method. The equipment includes kneader, milling machine, crusher, hydraulic press etc. Government and Nongovernmental agencies have responded to the problems by introducing the equipment to Shea butter processors' cooperative across the country through sensitization programmes on the benefit and the need to use modern processing technologies. The aim is to bring about increase in quality and quantity of Shea butter produced from the country and improves the income of processors as well as their living standard. 
Creative commons User License: CC BY-NC-ND

Abstracted by: EBSCOhost, Electronic Journals Service (EJS), Google Scholar, Directory of Open Access Journals (DOAJ),

Journal Seek, Scientific Commons,

Food and Agricultural Organization (FAO), CABI and Scopus
Journal of Agricultural Extension

Vol. 21 (1) February, 2017

ISSN(e): 24086851; ISSN(Print); 1119944X

http://journal.aesonnigeria.org

http://www.ajol.info/index.php/jae

Email: editorinchief@aesonnigeria.org

Despite all these, the quantity and quality of Shea butter produced in Nigeria is still low and the country is not recognized as an exporting country in the world. The perception of the processors to utilize these technologies is yet to be determined. It is on this backdrop that the perception of Shea butter processors to modern processing technology in Kwara State was embarked on.

The general objective of this study is to examine the perception of Shea butter processors on modern processing technologies in Kwara State and the specific objectives are to identify the socio economic characteristics of Shea butter processors, identify the enterprise characteristics of the processors, determine the level of awareness of processors on modern Shea butter processing technologies and their disposition to modern processing technologies in the study area.

The hypothesis of the study was:

Ho: There is no significant relationship between the level of awareness of processors to modern Sheabutter processing technology and their perception ofmodern processing technologies.

\section{Methodology}

The study was carried out in Kwara State, Nigeria. Data were collected by using questionnaire which was administered to Shea butter processors in the study area. A multi - stage sampling procedure was used. Purposive sampling technique was used to select Agricultural zones $A$ and $C$ out of the four agricultural development zones in the State because of the large number of Shea butter processors in these zones. Kaiama and Baruteen LGAs were also purposively selected from Zone A while llorin West and Moro L.G.As. were randomly selected from Zone $\mathrm{C}$. Random sampling technique was also used in selecting 30 respondents from the list of registered processors with the State ADP in each of the L.G.As selected from Zone $A$ and $C$ giving a 
Creative commons User License: CC BY-NC-ND

Abstracted by: EBSCOhost, Electronic Journals Service (EJS), Google Scholar, Directory of Open Access Journals (DOAJ),

Journal Seek, Scientific Commons,

Food and Agricultural Organization (FAO), CABI and Scopus
Journal of Agricultural Extension

Vol. 21 (1) February, 2017

ISSN(e): 24086851; ISSN(Print); 1119944X

http://journal.aesonnigeria.org

http://www.ajol.info/index.php/jae

Email: editorinchief@aesonnigeria.org

sample size of one hundred and twenty (120) respondents. Data were subjected to descriptive and PPMC statistical analysis.

Measurement of variables. Both the socio-economic and enterprise characteristics were obtained from the respondents. The level of awareness was obtained by listing modern equipment and asking them to identify the ones they know. Score of 1 and 0 was assign to aware and unaware respectively. A maximum value of 10 and minimum of 0 was obtained. The mean value of 7.79 was used to categorise as high or low for values above 7.79 and below respectively. The perception was measured on a five point Likert type scale using 25 perception statements bordering around the merit and demerit of using modern processing technologies. A maximum value of 125 and minimum of 0 was obtained. The perception scores obtained were classified as high (favourable) for all the values from 75.85 and above while the values below the 75.85 were considered as low (unfavourable).

\section{Results and Discussion}

\section{Respondents' Socio-economic Characteristics}

The age distribution as shown on Table 1 shows a mean value age of 47.5 years with $47.0 \%$ of the respondents between the age ranges of $40-49$ years and $34.4 \%$ between the age ranges of 50-59 years. This implies that younger people avoid Shea butter processing because it a tedious work but connect at later age to be able to meet their domestic needs. It is not about the physical strength but rather an inner motive that keeps one going no matter the odds. It could also explain why fewer men are involved in Shea butter processing despite their physical strength. The majority of the processors $(88.3 \%)$ were females. Men cannot exercise patience to go through all the Shea butter processing stages. It shows that women were more involved in Shea butter processing which agrees with the finding of Julius (2007) which states that across the African Shea zone, women are the traditional custodian of the Shea resources, with responsibility and control over all the stages of 
Creative commons User License: CC BY-NC-ND

Abstracted by: EBSCOhost, Electronic Journals Service (EJS),

Google Scholar, Directory of Open Access Journals (DOAJ),

Journal Seek, Scientific Commons,

Food and Agricultural Organization (FAO), CABI and Scopus
Journal of Agricultural Extension

Vol. 21 (1) February, 2017

ISSN(e): 24086851; ISSN(Print); 1119944X

http://journal.aesonnigeria.org

http://www.ajol.info/index.php/jae

Email: editorinchief@aesonnigeria.org

processing from collection of the fruits to transformation and marketing of Shea butter.

The marital status of the respondents reveals that the majority (86.6\%) were married. The majority of the respondents (72.6\%) were Muslims. Table 1 also revealed that an average household size of 8 person with $65.9 \%$ of the respondents having a household size range of between 5 and 8 persons. Fakayode et al., (2013) reported similar high value of between 6 and 10 household size (60.8\%) of processors in Kwara State. This implies that processors use members of their household to assist them in the processing of Shea butter. The respondents' educational level was low (83.1\%) with $31.4 \%$ of the respondents having primary education and $25.4 \%$ having adult education while $26.3 \%$ did not have formal education. This agreed with the findings of Salawu and Ayanda (2014) who reported low level of education $(92.2 \%)$ with the respondents having $53.3 \%, 22.8 \%, 12.2 \%$ and $3.9 \%$ of no formal, Quranic, uncompleted primary and completed primary education respectively in similar study area. It means that the respondents may not be better exposed to modern processing technologies on Shea butter as they generally had low level of education. 
Creative commons User License: CC BY-NC-ND

Abstracted by: EBSCOhost, Electronic Journals Service (EJS),

Google Scholar, Directory of Open Access Journals (DOAJ),

Journal Seek, Scientific Commons,

Food and Agricultural Organization (FAO), CABI and Scopus
Journal of Agricultural Extension

Vol. 21 (1) February, 2017

ISSN(e): 24086851; ISSN(Print); 1119944X

http://journal.aesonnigeria.org

http://www.ajol.info/index.php/jae

Email: editorinchief@aesonnigeria.org

Table 1: Socio-economic characteristics of Shea butter processors

\begin{tabular}{lll}
\hline Variables & Percentage & Mean \\
\hline Age & & \\
$20-29$ & 0.9 & 47.5 \\
30- 39 & 11.2 & \\
$40-49$ & 47 & \\
$50-59$ & 34.4 & \\
60 and above & 6.5 & \\
Sex & & \\
Male & 11.7 \\
Female & 88.3 & \\
Marital status & & \\
Single & 2.5 & \\
Married & 86.6 \\
Divorced & 2.5 & \\
Widowed & 3.4 & \\
Widower & 2.5 & \\
Separated & 2.5 & \\
Religion & & \\
Christianity & 24.8 \\
Islam & 72.6 \\
Traditional & 2.6 \\
House hold size & \\
1-4 & 2.6 \\
5-8 & 65.9 \\
9-12 & 29.2 \\
13-16 & 2.6 \\
Level of education & \\
No & & \\
education & 26.3 \\
Primary & 31.4 \\
Secondary & 11.0 \\
Adult & 25.4 \\
Tertiary & 5.9 \\
& & \\
\hline
\end{tabular}

\section{Characteristics of Respondents Enterprise}

The majority $(66.2 \%)$ of the respondents used calabash as a measurement for Shea butter production. (Table 2) The use of calabash as a measurement for Shea butter production in the study area is in line with Paine (1996) who found 
Creative commons User License: CC BY-NC-ND

Abstracted by: EBSCOhost, Electronic Journals Service (EJS),

Google Scholar, Directory of Open Access Journals (DOAJ),

Journal Seek, Scientific Commons,

Food and Agricultural Organization (FAO), CABI and Scopus
Journal of Agricultural Extension

Vol. 21 (1) February, 2017

ISSN(e): 24086851; ISSN(Print); 1119944X

http://journal.aesonnigeria.org

http://www.ajol.info/index.php/jae

Email: editorinchief@aesonnigeria.org

that basically calabashes facilitate the carriage and protection of the products against risks such as damage, spoilage and theft in the storage and distribution channel. It is also reveals that $58.4 \%$ of the respondents produced 11-20 calabashes per week, while few (1.7\%) produced 31- 40 calabashes per week which is regarded as high. This implies that most of them produce Shea butter at retail level. In terms of selling price, a larger proportion (49.1\%) sold Shea butter between the prices ranges of N1000- N1500 per calabash, $41.6 \%$ sold between N2100- N2500, while only $0.8 \%$ sold between N2600N3000. This variation in prices could be as a result of high cost of transportation caused by bad road, distance to market and cost of running the machines.

Table 2 also shows that $48.7 \%$ of the respondents used hired labour for Shea butter processing, 39.5\% made use of their family while $11.8 \%$ used both hired and family labour. This implies that Shea butter processing is labour intensive and time consuming thus processors will require additional labour in order to meet the demand for the product. The majority $(52.8 \%)$ of the respondents had 1-10 years of experience in Shea butter processing activities, while $32.2 \%$ had 11- 20 years of experience. Salawu and Ayanda (2014) also reported high values for years of experience of processors between 1-10 (21.1\%) and 11-20 (36.1\%) in Kwara State. This implies that the processors may not be having enough experience in processing activities thus they will require additional training to be able to function well. The majority of the respondents $(66.8 \%)$ marketed their product at retail level. It means that their production is low. 
Creative commons User License: CC BY-NC-ND

Abstracted by: EBSCOhost, Electronic Journals Service (EJS),

Google Scholar, Directory of Open Access Journals (DOAJ),

Journal Seek, Scientific Commons,

Food and Agricultural Organization (FAO), CABI and Scopus
Journal of Agricultural Extension

Vol. 21 (1) February, 2017

ISSN(e): 24086851; ISSN(Print); $1119944 X$

http://journal.aesonnigeria.org

http://www.ajol.info/index.php/jae

Email: editorinchief@aesonnigeria.org

Table 2: Percentage distribution of respondents based on enterprise characteristics

\begin{tabular}{|c|c|}
\hline Variables & Percentage \\
\hline \multicolumn{2}{|l|}{ Scale of Measurement } \\
\hline Calabash & 66.7 \\
\hline Kilogram & 33.3 \\
\hline $\begin{array}{l}\text { Number of Calabashes } \\
\text { Week }\end{array}$ & Per \\
\hline $1-10$ & 25.8 \\
\hline $11-20$ & 58.4 \\
\hline $21-30$ & 14.1 \\
\hline $31-40$ & 1.7 \\
\hline \multicolumn{2}{|l|}{ Amount per calabash } \\
\hline A1000- & 49.1 \\
\hline \#1600- \#2000 & 6.6 \\
\hline A 2100- & 41.6 \\
\hline A 2600- & 0.8 \\
\hline \#3100- $\$ 3500$ & 1.7 \\
\hline \multicolumn{2}{|l|}{ Sources of Labour } \\
\hline Family labour & 39.5 \\
\hline Hired labour & 48.7 \\
\hline Both & 11.8 \\
\hline \multicolumn{2}{|l|}{ Years of Experience } \\
\hline $1-10$ & 52.8 \\
\hline $11-20$ & 32.2 \\
\hline $21-30$ & 11.2 \\
\hline $31-40$ & 3.8 \\
\hline \multicolumn{2}{|l|}{ Marketing Channel } \\
\hline Retail & 65.8 \\
\hline Wholesale & 33.3 \\
\hline Both & 0.9 \\
\hline
\end{tabular}

\section{Awareness of Modern Processing Technologies}

Table 3 shows that the respondents were aware of modern processing technologies. The majority of the respondents were aware of pre-cleaner (98.3\%), Storage tank (94.2\%), milling machine (84.2\%) and crusher (84.0\%) technologies. This implies that these technologies are mostly known by the respondents. This could be attributed to the fact that they are less expensive and readily available to them as compared to the other modern processing technologies. 
Creative commons User License: CC BY-NC-ND

Abstracted by: EBSCOhost, Electronic Journals Service (EJS),

Google Scholar, Directory of Open Access Journals (DOAJ),

Journal Seek, Scientific Commons,

Food and Agricultural Organization (FAO), CABI and Scopus
Journal of Agricultural Extension

Vol. 21 (1) February, 2017

ISSN(e): 24086851; ISSN(Print); 1119944X

http://journal.aesonnigeria.org

http://www.ajol.info/index.php/jae

Email: editorinchief@aesonnigeria.org

The categorization of the respondents on their level of awareness of modern processing technology from table 3 reveals that $55.0 \%$ of the processors scored 7.69 and above and $45.0 \%$ scored below 7.69 , indicating that most of the respondents were aware of the modern processing technologies in the study area. Though the percentage of the processors that were aware of the modern processing technologies was high but not as expected which could be attributed to their low level of education. This can be improved upon through sensitization of the processors on the benefit of using the technologies

Table 3: Distribution of respondents based on awareness of modern processing technologies

\begin{tabular}{lll}
\hline $\begin{array}{l}\text { Modern } \\
\text { technologies }\end{array}$ & processing $\%$ & Scores \\
\hline $\begin{array}{l}\text { Pre- cleaner } \\
\text { Crusher }\end{array}$ & $98.3 \%$ & 0.98 \\
Screw hydraulic & $84.0 \%$ & 0.83 \\
Vibrating screen & $67.5 \%$ & 0.68 \\
Roaster & $74.2 \%$ & 0.74 \\
Expeller & $66.4 \%$ & 0.66 \\
Heated holding tank & $68.3 \%$ & 0.68 \\
Storage tank & $64.2 \%$ & 0.64 \\
Milling machine & $94.2 \%$ & 0.94 \\
Kneader & $84.2 \%$ & 0.84 \\
Mean of overall awareness & $69.2 \%$ & 0.69 \\
& $7.69($ range=0 -10) Sd. \\
\hline
\end{tabular}

*Multiple responses Source: Field survey 2012

\section{Respondents' Perception of Modern Processing Technologies}

Table 4 shows the perception of the respondents on modern processing technologies. Modern processing technologies might help to reduce drudgery has the highest mean score $(\bar{x}=4.36)$ with about two-third $(62.9 \%)$ of the respondents strongly agreed, $61.0 \%$ of the respondents agreed that using modern processing technologies may increase profit $(\mu=4.17)$ and $36.4 \%$ of the respondents believed that household income could improve with the use of modern processing technologies $(\mu=3.74)$. This profit increase may result from the fact that larger quantities of the product can be produced at a single 
Creative commons User License: CC BY-NC-ND

Abstracted by: EBSCOhost, Electronic Journals Service (EJS), Google Scholar, Directory of Open Access Journals (DOAJ),

Journal Seek, Scientific Commons,

Food and Agricultural Organization (FAO), CABI and Scopus
Journal of Agricultural Extension

Vol. 21 (1) February, 2017

ISSN(e): 24086851; ISSN(Print); 1119944X

http://journal.aesonnigeria.org

http://www.ajol.info/index.php/jae

Email: editorinchief@aesonnigeria.org

production, which usually would help to reduce production cost. Similarly, modern processing technologies may address problems with processing stages $(\mu=4.04)$ and saves time $(\mu=3.61)$. This corroborates the saying that a machine makes work easier, faster and eliminates fatigue thereby ensuring optimal time usage.

However, $67.2 \%$ of the respondents agreed that customers may prefer traditionally processed Shea butter, while only $1.7 \%$ strongly disagreed $(\bar{x}=$ 3.52). It follows that traditionally processed Shea butter still has an extra quality or edge with the respondents over modern technologies. The respondents agreed that lazy women appear to use modern processing technologies $47.5 \%(\bar{x}=3.48)$, which serves to inform that the respondents cherish hard work but may need some enlightenment.

Table 4 also reveals that modern processing equipment are too expensive (44.9\%), $(\bar{x}=2.25)$, about $43.0 \%(\bar{x}=2.28)$ of the respondents agreed that modern processing technology is only accessible to rich processors and $39.7 \%(\bar{x}=1.83)$ of the respondents believed that modern processing technology is difficult to handle. The categorization of the respondents' perception of modern processing technology from table 4 reveals that $62.5 \%$ $(\bar{x}=75.85$ and above $)$ of the respondents had high perception towards the use of modern processing technology.

Despite the high cost of the machinery and lack of knowledge on the technical know-how of the machines, majority of the respondents had a positive perception towards the technologies and its utilization which can be attributed to their high level of awareness of the modern processing technologies. The perception can be improved through sensitization of the processors and Government can encouraging them to use the modern processing technologies by assisting them to acquiresome of the machines needed for processing. 
Creative commons User License: CC BY-NC-ND

Abstracted by: EBSCOhost, Electronic Journals Service (EJS),

Google Scholar, Directory of Open Access Journals (DOAJ),

Journal Seek, Scientific Commons,

Food and Agricultural Organization (FAO), CABI and Scopus
Journal of Agricultural Extension

Vol. 21 (1) February, 2017

ISSN(e): 24086851; ISSN(Print); 1119944X

http://journal.aesonnigeria.org

http://www.ajol.info/index.php/jae

Email: editorinchief@aesonnigeria.org

Table 4: Distribution of respondents based on their perception of modern processing technology

\begin{tabular}{|c|c|c|}
\hline Statements & mean & SD. \\
\hline Use of modern technologies may increase profit. & 4.17 & 0.79 \\
\hline Using modern technology may lead to high losses & 2.23 & 0.87 \\
\hline Using modern technology could lead to increase productivity & 3.79 & 0.91 \\
\hline The cost of production in using modern technology is low & 2.23 & 0.80 \\
\hline Modern technology saves time & 3.61 & 0.95 \\
\hline It is very difficult to find & 2.39 & 0.85 \\
\hline $\begin{array}{l}\text { The use of modern processing technology will conserve } \\
\text { processors energy }\end{array}$ & 3.71 & 0.91 \\
\hline It could be less hygienic & 2.29 & 0.88 \\
\hline It is only accessible to rich processors & 2.28 & 0.85 \\
\hline $\begin{array}{l}\text { Household income could improve with the use of modern } \\
\text { technology }\end{array}$ & 3.74 & 0.97 \\
\hline Lazy women appear to use modern technology & 3.48 & 1.02 \\
\hline Traditionally processed Shea butter may have higher demand & 3.52 & 0.99 \\
\hline $\begin{array}{l}\text { Modern technology are operated on individual basis because } \\
\text { of its complexity }\end{array}$ & 2.52 & 1.22 \\
\hline $\begin{array}{l}\text { Processors may use more of modern technology because of } \\
\text { the stressful nature of traditional processing }\end{array}$ & 3.65 & 0.92 \\
\hline Modern processing may be less hazardous & 2.33 & 0.94 \\
\hline Modern processing equipment are expensive & 2.25 & 0.88 \\
\hline Modern processing tech may enhance good quality butter & 3.68 & 0.94 \\
\hline Large family size encourage processors to use modern tech & 2.33 & 0.89 \\
\hline Modern processing are always easy & 3.62 & 0.92 \\
\hline Traditional processing may be labour intensive & 3.58 & 0.96 \\
\hline Modern processing appear not to be gender sensitive & 2.28 & 0.95 \\
\hline Using modern processing might help to reduce drudgery & 4.36 & 1.08 \\
\hline Customers may prefer traditionally processed Shea butter & 1.95 & 0.75 \\
\hline Modern processing tech are difficult to handle & 1.83 & 0.91 \\
\hline $\begin{array}{l}\text { Modern processing may address problems with processing } \\
\text { stages }\end{array}$ & 4.04 & 1.04 \\
\hline $\begin{array}{l}\text { Mean of overall perception } \\
\text { SD. } 9.60\end{array}$ & \multicolumn{2}{|c|}{$75.85($ range $=0-125)$} \\
\hline
\end{tabular}

\section{Relationship Between Respondents' Level of Awareness and Perception of Modern Processing Technology}

Table 5 shows that there was significant relationship between the level of awareness of the respondents and perception of modern processing technology $(r=0.182, p=0.046)$. There was positive relationship between awareness and perception. It implies that as the respondents' level of 
Creative commons User License: CC BY-NC-ND

Abstracted by: EBSCOhost, Electronic Journals Service (EJS),

Google Scholar, Directory of Open Access Journals (DOAJ),

Journal Seek, Scientific Commons,

Food and Agricultural Organization (FAO), CABI and Scopus
Journal of Agricultural Extension

Vol. 21 (1) February, 2017

ISSN(e): 24086851; ISSN(Print); 1119944X

http://journal.aesonnigeria.org

http://www.ajol.info/index.php/jae

Email: editorinchief@aesonnigeria.org

awareness of modern Shea butter processing technologies increases, their perception towards the modern processing technologies increases too.

Table 5: Relationship between the level of awareness of respondents and the perception to modern processing technology

\begin{tabular}{ll}
\hline Variable & r-value \\
\hline Awareness & $0.182^{*}$ \\
perception & \\
\hline${ }^{*} p \leq 0.05$ &
\end{tabular}

\section{Conclusion and Recommendations}

The Shea butter processors' awareness level was high and they had a high positive perception towards the modern processing technologies which can be improved upon. The perception statements identify high cost and technical know-how as the major constraints to the use of the technologies.

Their level of awareness and perception can be improved upon through sensitization of processors on the benefits and training on how to use the modern processing technologies in the local languages for the people to understand and address the problem of technical know-how.

Government and NGOs should assist the processors to procure modern processing technology to help solve the problem of high cost. Lastly, the processors should be encouraged to form functional cooperative societies to enable them get a good bargain for their products as well as for easy procurement and distribution of credit, loan and processing inputs to the processors.

\section{References}

Addaquay, J. 2004. The Shea butter value chain: refining in West Africa. West Africa Trade Hub(WATH). Technical Report No. 3. Washington, DC: USAID.

Ademola, A.O., Oyesola, O.B. and Osewa, S.O., 2012. Assessment of Shea butter processing among rural dwellers in Atisbo Local Government Area of Oyo state, Nigeria. European Journal of Business and Social Sciences Vol. 1. No. 6: Pp. 1-8. 
Creative commons User License: CC BY-NC-ND

Abstracted by: EBSCOhost, Electronic Journals Service (EJS), Google Scholar, Directory of Open Access Journals (DOAJ),

Journal Seek, Scientific Commons,

Food and Agricultural Organization (FAO), CABI and Scopus
Journal of Agricultural Extension

Vol. 21 (1) February, 2017

ISSN(e): 24086851; ISSN(Print); $1119944 X$

http://journal.aesonnigeria.org

http://www.ajol.info/index.php/jae

Email: editorinchief@aesonnigeria.org

Bonkoungou, E.G (2005): The shea tree (Vitellaria paradoxa) and the Africa shea parklands. Proceedings of the international workshop on processing and marketing of Shea products in Africa, Dakar, Senegal.4-6 march 2002.Technical paper No 21: Pp. 51-59

Fakayode, S. B, Akangbe, J.A, Akinseye, O. B and Adesuyi W. S. 2013. Job incentives for rural women in Nigeria: An appraisal of The Shea-butter extraction option. Developing Country Studies Vol. 3. No.3: Retrieved online from www.iiste.org on $9^{\text {th }}$ September 2014.

Food and Agricultural Organization Statistic, 2015. Karite (Shea nut) production in Nigeria from 1961-2013. Food and Agriculture Organization of the United Nations Statistics Division. Rome. Accessed online from faostat3.fao.org/home/E on $9^{\text {th }}$ July 2015.

Garba, I. D., Nwawe, C N., Osiakede I. L. (2011). The Potential Of Shea Nut Tree To The Nigerian Economy. International Journal Of Agricultural Economics And Rural Development. Pp. 62-72. Retrieved august 28, 2011, from http:http//www.iaerd.latechaeee-edu.com.

Harsch, E. (2001). Making trade work for poor women. Africa Recovery journal Vol. 15. No.4: Pp.6.

Julius N. F. (2007). Research and development of Shea tree and development of Shea tree and its product. Online material retrieved August 28, 2011 from http://www.solution-site.org/cat11-so11/19.htm

Nigerian Institute for Oil Palm Research (NIFOR) .2005. Brief on the Institute and highlights of achievements in research and production. Gift-Prints Associates, Benin City, Nigeria. Pages iii and 25.

Paine, F.A. 1996. The Packaging Users Handbook. Blackie Academic and Professional Limited, London, UK. pp. 3-5.

Salawu O. L. and Ayanda I. F. 2014. Assessment of the contribution of Shea butter processing to poverty reduction among women in Kwara State, Nigeria. Journal of Sustainable Development in Africa. Volume 16. No. 3; Pp. 7

Yinug, F. and Fetzer, J. (2008). Sub-Saharan Africa: Factors affecting trade patterns of selected industries (No. Second annual report). Washington, DC: United States International Trade Commission (USITC). Cited in Rousseau Karen, Denis Gautierand D. Andrew Wardell. 2015. Coping with the upheavals of Globalization in the Shea Value Chain: The maintenance and relevance of upstream Shea nut supply chain organization in Western Burkina Faso. World Development Vol. 66. Pp.: 414. An online material accessed from http://dx.doi.org/10.1016/j.worlddev.2014.09.004 on 4th October, 2015. 